\title{
FEJLESZTÉSI MÓDSZEREK ÉS ÖTLETEK ÓVODÁS ÉS KISISKOLÁS GYERMEKEK SZÁMÁRA
}

\author{
Szerző: \\ Babos Borbála \\ Lektorok: \\ Mező Katalin \\ Debreceni Egyetem \\ Schréder Veronika \\ Debreceni Egyetem \\ Szabó Edina \\ Debrecni Egyetem \\ Nemes Magdolna \\ Debreceni Egyetem \\ Szerző e-mail címe: \\ borbala.babos@hotmail.com \\ Babos Borbála (2016): Fejlesztési módszerek és ötletek óvodás és kisiskolás gyermekek \\ számára. Különleges Bánásmód, II. évf. 2016/4. szám, 95-104. DOI 10.18458/KB.2016.4.95
}

\begin{abstract}
Absztrakt
A fejlesztő pedagógusok munkája nem egyszerü. Különböző korú, eltérő problémájú gyermekekkel foglalkoznak. Ez a rövid tanulmány talán abban segít, hogy saját kreativitásuk használatával, némi támpontot kapjanak a használható módszerekről, néhány konkrét játék, könyv ajánlásával. A betekintés motivációt ad a pedagógusnak önmaga képzésére, hogy mélyebben beleássa magát egyes módszerek megismerésébe.
\end{abstract}

Kulcsszavak: szorongás, iskolai problémák, magatartásprobléma, feszültségoldás, önismeret, módszerek, játék

Diszciplinák: pedagógia, pszichológia

\begin{abstract}
DEVELOPMENTAL METHODS AND IDEAS FOR PRESCHOOL AND PRIMARY SCHOOL CHILDREN

The developer educators' job is not a simple one, children of different age and various problems are to be treated. This short study may help you to have an idea regarding applicable methods using your own creativity, and it recommends a few available games and books. The introspection motivates the educator to train himself to be able to know certain methods more deeply.
\end{abstract}

Keywords: anxiety, problems at school, behavior problems, stress-relaxation, selfrecognition, methods, games

Disciplines: pedagogy, psychology 
E tanulmány azt mutatja be, hogy fejlesztő pedagógusként milyen lehetőségek nyílnak számunkra azon óvodás és kisiskolás gyermekek megsegítésére, akik arra rászorulnak, mert magatartásproblémával küzdenek, tanulási nehézségeik vannak, hátrányos helyzetüek vagy éppen személyiségük fejlődésében zavar keletkezett. Példákkal és játékötletekkel vesszük sorra azokat a lehetőségeket, amihez nem feltétlenül szükséges szakmai képzés. Bizonyos területeken természetesen elengedhetetlen, hogy olyan szakember foglalkozzon a gyermekkel, aki megfelelően képzett és érti a történések miértjét, de a drámajátéktól a jógáig terjedően nem professzionális fejlesztőként is meríthetünk ötleteket segítő tevékenységünkhöz.

\section{Mitől szoronghat egy gyermek?}

Hétköznapok, elfoglaltság-pihenés. Manapság nagyon kevés idő jut a gyerekekre, a minőségi családi időtöltésre, az igazi törődésre. Már az óvodában minden délután programok várják a gyermekeket, a szülök pedig beleesnek a csapdába: „A gyereknek mindent ki kellene próbálnia, hisz a társaitól különben majd lemarad! ha nem megy sport versenyre, nem játszik hangszeren, mi lesz így belöle?!”.

Meg kell találni a gyermeknek megfelelő életstílust. Azzal foglalkozzon, amihez igazán kedve van! Akkor és úgy, ahogy neki megfelelö, illetve addig, amíg ebben örömét leli, és nem fárasztja. Addig, amíg a szülö is bírja, hogy ide-oda hordja a gyerekét/gyerekeit és a nap nem áll másból, mint logisztikából. Este aztán már csak a vacsora és a gyors fürdés fér bele az időbe, meg a kétségbeesés, hogy nem is volt együtt a család.

A pihenést sokszor a tévé, az internetezés, a számítógépes játékok jelentik. Természetesen ezzel nincs probléma, ha van ésszerü korlátja. De, ha a szülők is ezt használják hobbiként, pihenésként, ne várjunk mást a gyermektöl sem.

A gyerekek a televízióból olyan információkat szerezhetnek, amit nem tudnak elraktározni. Nem értik, rosszul értelmezik, saját kis világuk nyelvére fordítják. Ha nincs ott a szülő vagy a gyermek nem kérdez, a szülőnek gyakran nincs is róla tudomása, honnan tudhat bizonyos dolgokat a gyermeke. Ne is említsük a nem nekik való rajzfilmek, felnőtt filmek mellett a sztárok világát. A valóság show-kat, a tehetségkutató műsorokat, a gyereksztárokat bemutató csillogó-villogó világot. A gyerekek ezt látják példának, ilyenné szeretnének válni, vonzza őket a fény, a ragyogás, a sztárolás. Nem látják a negatív oldalát, fogalmuk sincs, mennyire nehéz, fárasztó, embert próbáló, megterhelő a sztárság.

Családi nehézségek: számtalan kisebb-nagyobb konfliktus fordul elö minden családban. Legyen az egy anyagi megterheltség, egy kistestvér, egy alkoholista szülő vagy csak egy nehezebb korszak, amikor a szülők nem értenek egyet mindenben, sok a veszekedés. A gyerek akár hallja, akár nem, érzi, hogy gond van. A szülők azt hiszik, hogy nem olyan nagy dolog, hisz úgysem figyel, vagy már alszik, amikor véletlenül kiabálnak. Így még a ,jobb” családokban is előfordul, hogy a gyermek olyan tüneteket produkál, amit a szülők nem tudnak értelmezni.

Iskolai problémák: az iskolai követelmények magasak. Ha nem is minden általános iskolában, és nem konkrétan a tananyag sok, egy első osztályos gyermeknek igen sok új helyzethez kell alkalmazkodnia. Vigyázni kell a dolgaira, minden nap be kell csomagolni a táskáját, házi feladatot kell írnia, megfelelni a tanító néninek, figyelnie az órán, betartani a szabályokat stb. Az elsajátítandó ismeretanyagról nem is szólva, amivel a pedagógusok sem tudnak lépést tartani.

Szülőként hiába választunk körültekintően, nem biztos, hogy a tanító és a gyermek kapcsolata mindig felhőtlen. Bárhol előfordulhatnak konfliktusok. Akár csak egy félreértés, akár egy nagyobb horderejü dolog, a gyermeket megviseli. Ugyanígy a gyermek-gyermek közötti feszültségek, amik igen gyakoriak ebben az életkorban, hiszen ilyenkor a legnagyobb a kortársak szerepe. Ma a barátom, holnap már mással játszik a szünetben. Ezek az arra érzékenyebb gyerekeknél igen komoly feszültséget okoznak. Szorongást idéz elő a 
beilleszkedési nehézség, ha a gyermek nem tud, vagy valamiért nem akar az osztályhoz igazodni.

Ha a gyermeknek részképesség zavara van, ha külön fejlesztésre jár, ha viselkedési problémái vannak, ezek mind „mássá” teszik őt, akármennyire is próbálkoznak a pedagógusok ugyanolyan gyermekként fogadni és kezelni őt, mint társait. Elég, ha logopédiára jár egy gyermek, és a többiek ezt nem tolerálják kellőképpen. Nem biztos, hogy az a gyermek azért szorong, mert tudja, hogy ö nem tud olyan gyorsan olvasni, mint a többiek, lehet, hogy társai visszajelzései nem megfelelőek.

A csoport milyensége, összetétele, a közösség is meghatározó. Elöfordulnak olyan szerencsétlen helyzetek, amikor egy osztály vagy csoport olyan gyerekek által „,vezérelt”, akik nem fogadják el a másikat, akik agresszívek, akik családi háttere egész más, mint a többieké. Félelem, parancsolgatás, behódolás, súlyos esetben testi bántalmazás is megjelenhet a gyermekek közt. Természetesen a pedagógus sokat tehet a csoport légkörének kialakításáért!

\section{Mit tehet a fejlesztő pedagógus?}

$\mathrm{Az}$ alábbiakban szedjük csokorba a fejlesztőpedagógiai beavatkozás legelemibb lehetőségeit:

- A gyermek megfigyelése iskolai vagy óvodai környezetében, beszélgetés a pedagógussal, tanítóval, óvodapedagógussal. Tünetek, problémák feltárása.

- Kapcsolatfelvétel a szülökkel, családlátogatás. Ezen belül megtörténhet a gyermek bemutatása, és megismerhetők személyiségjegyei, temperamentuma, szokásai, mindennapjai, félelmei, problémái, viselkedése, testvéreivel való kapcsolata, iskolai teljesítménye, az iskolához való viszonya, barátai, kortárs kapcsolatai-ahogyan otthon látják. A szülőkkel folytatott beszélgetés során a problémák feltárása, tanácsadás, szituáció elemzés, terv készítése is lehetséges.

- Megoldások az intézményben:

- ültetés,

- kiemelt figyelem,

- a gyermekre szabott követelmények, szabályok kialakítása,

- szakemberekkel való együttmüködés,

- csoportos fejlesztés a kiemelt figyelmet igénylö gyermekekre építve,

- egyéni fejlesztés,

- különböző fejlesztő célú foglalkozások: csoportfoglalkozások, bábjáték, meseterápia, müvészeti terápiák (festés, rajz, zene), mozgásterápia-sporttevékenység, kirándulás, jóga, relaxálás, drámajáték.

Ez utóbbi pontot tekintsük át részletesebben is!

\section{Csoportfoglalkozások}

Céljuk: önismeret, empátia, együttmüködés, szociális kapcsolatok fejlesztése, önértékelés korrigálása, énképhiányosság feltárása, a csoport összetartozásának kialakítása.

A foglalkozások alapja az őszinte, személyes kapcsolat kialakítása, a megfelelő légkör megteremtése. Néhány játék, melyek a fent említett képességek fejlesztésére szolgának (különböző életkorú gyermekek számára):

1. Detektívjáték: A gyermek problémájával hasonló történet mesélése, feldolgozása. A nem helyes viselkedés tudatosítása, új megoldás keresése, közösen.

2. „Leszokni-megtanulni”: Nagyobb gyermekeknél táblázatot készíthetünk, amiben tükröződik, hogy melyik az a viselkedés, amivel a gyermek tisztában van és el szeretné hagyni. Például nem akarja minden nap megszámolni a téglákat az iskolához vezető úton. Erről szeretne leszokni, viszont szeretné megtanulni, hogyan menjen úgy 
minden nap iskolába, hogy ne érezze kellemetlenül magát (pl.: pozitív dolgokra koncentrálni).

3. Hangulattábla: Kinek, milyen a hangulata az adott napon. Jelölhetjük különböző mimikájú arcokkal.

4. Szabálytábla: A legfontosabb szabályok rögzítése (akár óvodában is!), a szabály megszegésének következményével együtt.

5. Vakvezetés: Egy gyermeknek bekötjük a szemét, a társa hangszerrel jelzi, merre kell mennie.

6. „Utazzunk együtt!” játék : Egy szigetre költözünk, kit vinnél magaddal és miért?

7. Szerepjátékok: Bizonyos helyzetek, konfliktusok eljátszása. Kicsiknél a pedagógus is beszállhat a játékba, irányíthat, majd később már önállóan dolgozzák fel a gyerekek a problémát.

8. Éhes kígyó: A csoport vezetője a kígyó feje, a középső gyerekek a teste, az utolsó gyermek pedig a farka, akinek egy zsák van a kezében. A kígyó tagjai egymás vállát/derekát fogva haladnak. Az a feladat, hogy meghatározott idő alatt minél több „ételt” (különböző tárgyakat) gyüjtsenek össze. Ha felvette a „fej”az adott tárgyat, akkor megállnak, hátra adják az ételt az utolsó gyermeknek. A „kígyó farka” a tárgyat beteheti a zsákjába, és indulhat tovább az ételkeresés. Cél, hogy minél gyorsabban és összehangoltabban „lakjanak jól” a kígyók. A játék addig tart, amíg minden tárgy el nem fogy a játéktérről.

9. Kiscsibe: Egy „láthatatlan” csibét vagy bármilyen apró, fiktív állatot, tárgyat adunk körbe egymásnak, marokról marokra. Nagyon kell vigyázni, ki ne essen a kezükből!

10. „Kedvellek, mert...” mondatbefejező játék: Körben ülnek a gyerekek, labdát adogatnak egymásnak. Akitől kapja a labdát, arról elmondja, hogy miért kedveli őt, mi szeret benne.

11. „Nem akarok ilyen lenni!” játék: Kiosztjuk a szerepeket, lehetőleg olyan „,negatív” viselkedési formákat, amiket a gyerekek sem tartanak elfogadottnak. Erre a szerepre felkészülnek, tárgyakat, eszközöket gyüjtenek hozzá, majd közösen eljátsszák. A történetet ök találhatják ki.

12. Kapcsolatteremtés zenére: Klasszikus, megnyugtató zenére szabadon mozoghatnak a gyerekek, nem szabad megérinteniük egymást. Ha a zene elhallgat, megmerevednek. Tovább szól a zene, majd a gyerekek úgy mennek el egymás mellett, hogy súrolják egymás vállát, kezét. Ez így megy tovább, a végén párt keresnek maguknak és tükörjátékot játszanak, egymás mozdulatait utánozzák, zenére.

13. Jóságos Manó: Minden gyerek húz egy nevet, annak a gyereknek lesz titokban a jótevője. Pár héten keresztül apró meglepetéseket rejtenek el, segítik egymást, persze titokban. A végén megbeszéljük közösen, ki lehetett a jóságos manó, ki, minek örült a legjobban.

14. „Menj a hang után!” játék: A szoba egy-egy részében helyezkednek el a gyerekek, mindenki kitalál egy hangsort és ismételgetni kezdi. Közben figyeli a többiek hangját, és a neki szimpatikus hang irányába kezd el csukott szemmel elindulni. Így egy-két ember köré csoportosulnak a gyerekek.

15. „Mérges vagyok!” játék: Papír, ceruza szükséges hozzá. Leírják a gyerekek, mit tesznek, ha dühösek. Ezután megbeszéljük, mi az, ami másnak fájdalmat okoz, ezt kihúzzuk a listáról.

\section{Bábjáték}

A bábozás elsősorban játék, örömet jelent a gyermek számára. Játékos módon sajátít el ismereteket, teremt kapcsolatot a világgal, környezetével, miközben élményeit, benyomásait dolgozza fel. Segít a kapcsolatok kialakításában, a szociális képességek fejlesztésében, hiszen 
a gyermek érzékenysége természetes módon nyilvánul meg. Hamar felszínre kerülnek a gyermek érzelmei, akár visszahúzódó, félénk, akár agresszív, bizonytalan, szeszélyes gyermekről van szó. Önállóságot kíván, ezért önbizalmat, bátorságot ad. A bábu élőként hat, így fejleszti a gyermek érzelmi, akarati életét és fantáziavilágát. Elfojtásokat, vágyakat, indulatokat lehet rajtuk keresztül kiélni, a gyermek bárkivé válhat, következmények nélkül. A negatív indulatok, feszültségek levezetődnek, feloldódnak. A bábjátékon keresztül új probléma- megoldási lehetőségeket nyújthatunk a gyermek számára. Azok a gyerekek, akik minden közeledést visszautasítanak, bábuval sokkal könnyebben fel lehet őket oldani, a pedagógus számára egyértelmüvé válnak a belső konfliktust okozó helyzetek, a gyermeket foglalkoztató történések.

A pedagógus feladata, hogy kiválassza azt a mesét, történetet, ami megfelelő a gyermek számára, amiben kiélheti nyomasztó gondolatait, feszültségét, ahol jól érzi magát. Nem mindegy, hogy egyéni foglalkozást tartunk vagy csoportosat, mi a célunk. Természetesen egy gyermek problémáját nem oldhatjuk meg mindig csoportban, de a megfelelö mese minden gyermek számára pozitív értékkel bír.

A bábozás nem feltétlenül egy mese eljátszását jelenti, lehet egy terápia kezdő mozzanata, egy beszélgetés kezdeményezésére alkalmas módszer, egyéni fejlesztés esetén, lehet egy sérült gyermekkel való kapcsolatteremtés módszere. Ha a gyermek nem akar beszélgetni, megosztani problémáját, így hamar feloldódik. Kialakulhat belöle egy saját történet, amit a gyermek és a pedagógus egyaránt irányít, amely segít felderíteni a kimondatlan aggodalmakat, és ami segít a feszültség oldásában. A nagyon nehezen megnyíló gyermekek esetében bábozhat a pedagógus is, úgy, hogy a gyermek csak néző. A gyermek így is beszélgethet a bábbal, válaszolhat kérdéseire, vagy csak átélheti „kívülröl” a történetet, már ez önmagában is segít a lelki megnyugvásban. Ráadásul a bábokat sokféleképpen, együtt is elkészíthetik!

Marék Veronika (2013) „Laci és az oroszlán” címü meséje például alkalmas bábokkal történő eljátszásra. Segít a félelmek leküzdésében, mintát ad a bátor viselkedésre, erőt, támogatást nyújt a zsebben lapuló „tárgy”, az oroszlán, aki a kisfiúval van a nehéz helyzetekben.

\section{Mese}

Amikor mesélünk a gyermeknek, ő maga alkot képet azokból az érzésekből, amit mi közvetítünk számára. Ezért szerencsés, ha nem mutatunk képet a gyermeknek, hiszen akkor már befolyásoljuk képalkotását. A gyermeki félelmek formát öltenek, megjelennek bizonyos szereplőkben, a problémái láthatókká válnak a történésekben, természetesen szimbolikus formában. Azért kéri a gyermek ugyanazt a mesét újra és újra, mert egyre jobban érzi magát a cselekmény hallgatása közben, oldódik feszültsége.

A népmesék különösen alkalmasak az útkereső, bizonytalan gyermek számára, hiszen a legkisebb királyfi, a leggyengébb testvér, az apró állatok mind keresztülmennek a nehéz, bonyolult úton, ami veszélyekkel kikövezett, de a végén mindig elnyerik méltó jutalmukat, és a fájdalmakon, nehézségeken keresztül megszerzik maguknak, amire vágynak, elérik céljukat.

Szerepeljen itt néhány könyv (mese) ajánlat, melyek konkrét félelmek leküzdésében lehetnek hasznosak:

- Óvodától, iskolától való félelem: Kormos (2016a,b).

- Alvásnehézségek: Ende (2003), Mészáros (2015).

- Óvodás-és kisiskoláskori problémák, mindennapi helyzetek megoldásainak segítésére: Beck (2013, 2014a,b, 2015, 2016).

- Feszültség levezetésére, színezők, „cselekvő” könyvek: Smith (2016), Basford (2015). Megjegyzés: nagyon sok színező könyv jelent meg az utóbbi időben, különböző témákban. A Szerző saját tapasztalata szerint a gyermekekkel történő közös 
színezéseink alkalmával egyszer csak megered a nyelvük, s bármiről lehet velük beszélgetni.

- Boszorkányoktól való félelem: Boldizsár (2014)

- Szorongás csökkentésére óvodásoknak: Lengyel és Rónai (2012).

- Visszahúzódó, bizonytalan gyermekek számára: Kertész (2016).

\section{Müvészetek:}

zene, tánc, írás, vizuális múvészetek (rajzolás, festés, kreatív kézmüveskedés)

A különböző müvészeti ágak hasznos eszközei a feszültségek levezetésének, a nehézségek, problémák kivetítésének, feltárásának. A gyerekeket meg kell tanítanunk a számukra legmegfelelőbb, hozzájuk legközelebb álló módszerre, amivel enyhíthetik belsö szorongásaikat, fájdalmaikat, dühüket. Az iskolás gyermek már könnyebben megfogalmazza, mi bántja, és tudatosan tud olyan tevékenységet választani, ami segít nyomasztó hangulatát megszüntetni. A tehetséges gyermekek számára különösen inspiráló lehet ez a módszer. Általában tehetségük mellé társulhat magatartásprobléma, ami miatt nehezen ismerhető fel, hogy ők kiemelkedőek valamiben. A zene, a tánc, a mozgás segítheti az ellazulásban, önmaga kifejezésében, elfogadásában.

Önmagában a zenehallgatás is segíthet. Akár a klasszikus, nyugodt zenemüvekre való szabad mozgás, akár egy rockzenére való ugrálás, vagy egy „gondolatkirándulás” nyugtató, relaxáló muzsikára.

Óvodai csoportokban elmehetünk például a „Varázserdőbe”, s ekkor hol zenére, hol csendben indulhatunk el, körben járva. Néhány lassú, bemelegítő gyakorlat után (lábujjhegyen kelünk át a patakon, guggolva bújunk be a barlangba stb.) leülünk a rétre nézelödni, állatokat lesni, uzsonnázni. Máskor csukott szemmel a földön fekszenek a gyerekek, s a pedagógus mesél. Hol vagyunk, mit látunk, mit érzünk? Nem beszéljük meg a történéseket, csak, ha igényük van rá a gyerekeknek, ha ők kezdeményezik.

Néhány játékos gyakorlat a müvészetek területével kapcsolatban:

- Mit érzel? Mi jut eszedbe a zenéről? Hogyan érzed magad zenehallgatás közben? Ezeket nagyobbak leírhatják, kicsik lerajzolhatják vagy megbeszélhetjük, miután a zene elhallgatott.

- Rajzolás, festés klasszikus zenére. Szabadon, sok színt biztosítva a gyermek számára, kötöttségek nélkül.

- A szabad mozgás, tánc különböző stílusú zenékre, már attól is feszültségoldó, hogy nincsenek határok. Óvodásoknál ez még nehéz gyakorlat, gyakran nem tudnak mit kezdeni magukkal. Ilyenkor az óvodapedagógus példája segít. Ezekben a játékokban a sérült gyermekek is szívesen részt vesznek, itt nem kell megfelelniük, nem „rosszabbak”, mint társaik, önmagukat adhatják.

- Rimszkij-Korszakov: A dongó című művéhez történetet találunk ki, s eljátszuk azt. A koreografált táncnak is megvan a maga hatása, szabályokhoz kötött, mégis élvezetes, az együttmozgás öröme erőt ad. Már óvodában is használhatjuk, például ünnepekkor, bemutatókon a szülőknek is előadhatjuk.

- Minden írni már tudó gyereknek ajánlhatjuk, hogy vezessenek naplót. A naplóvezetés sajátossága, hogy általában akkor írja az ember, ha valamilyen érzelmekkel telitett (kellemes/kellemetlen) élmény éri őket. Ezt az élményt akár elmeséli valakinek, akár nem, leírva mindenesetre már tudatosítja azt, s esetleg a feszültségét is oldja ezzel.

- Kreatívabb gyerekek írhatnak mesét, történetet, verset is. Sok szép szerelmes vers született már ilyen indíttatásból! Deákné B. Katalin (2013) „Befejezetlen történetek” címü füzete éppen erre való, már négy éves kortól. Matricákat lehet ragasztani, rajzolni lehet, a történetek címe adott. A felnőtt leírja, amit a gyermek diktál. 
- A kézmüveskedés sok gyermek számára vonzó, vagy megfelelő motiválással azzá tehető. A rajzok visszaadják a gyermek érzéseit, gondolatait, azáltal közvetíti a világ felé, hogyan is érzi magát benne. A finommozgás fejlesztésén túl, a csoportos tevékenységek közben lehet beszélgetni, zenét hallgatni, segíteni egymásnak, megvitatni, hogy ki, miért, hogyan gondolja az adott müvét. Lehetőség nyílik a pedagógus számára az irányított beszélgetésekre, a szociális érzék fejlesztésére, egymás elfogadásának fontosságára, a csoportbeli pozitív viszonyok kialakítására. Nem utolsó sorban teret enged a kreativitásnak. Alkalmas erre bármilyen tárgy készítése is, kézmüves foglalkozás különböző technikákkal. A produktum megalkotása örömet nyújt, büszkeséget ad, tapasztalatot a gyermek számára önmaga képességeiről. Példa: karácsonyi manók vagyunk, kiállítást rendezünk müveinkböl. Csajkovszkij „Diótörő”jének hallgatása közben, hatalmas papírokra festünk, együtt vagy külön-külön, ahogy a gyerekeknek kedvük tartja. Mi vagyunk a festők!

\section{Mozgás, sport}

A mozgás, sport egyértelműen elengedhetetlen a gyermek testi és lelki fejlödésében, személyiségének alakulásában. Ha nem akar a gyermek kifejezetten sportolni, a szabad levegőn való mozgás is megteszi. Kiszabadul egy kis időre az iskola falai közül, szaladgálhat, kiabálhat, nincs korlátozva a mozgásban. Jobban tud teljesíteni egy ilyen pihenő után, társaival kapcsolatokat alakít. Gondolatai nem zavarják, elfelejti aggodalmait, felszabadul. Az irányított szabályjátékok már okozhatnak némi frusztrációt, amíg a gyermek nem képes elfogadni, hogy következményekkel kell számolni, ha nem tartja be a megbeszélt feladatot. Az együtt játszás öröme és a játékok mondanivalója segít a feszültségek kiengedésében, pl. a farkas elkapja a nyulakat. Félelmeit mozgással egybekötve kijátszhatja. Különösen fontos ez a magatartásproblémákkal küzdő gyermekek számára, azoknak, akiknek folyamatosan teljesíteniük kell, és nem érzik egyenrangúnak magukat a többiekkel. Akikkel folyton csak a baj van, mindig ők a hibásak, akikre mindig rá kell szólni...

Az óvodában (és az iskolában is) a mindennapos testnevelés, a napközbeni mozgásos játékok, a „nagytestnevelés” foglalkozás alkalmas a mozgáskultúra kialakítására. Egyéni fejlesztések alkalmával is számtalan mozgásos feladat beilleszthető a problémával küzdő gyermekek számára, ami mozgásának fejlődésében és a feladatok közti pihenésben is szerepet játszik.

Íme néhány példa mozgásos játékokkal kapcsolatban:

- Akadálypálya: páros játék, az egyik gyermek vezeti „vak” társát végig a pályán. Az a pár győz, aki a leggyorsabban halad végig a pályán.

- Páros egyensúlyozás: babzsákot, labdát fognak össze a gyerekek, különböző testrészeiknél (fej, has, hát). A tárgyat egy kijelölt helyre kell eljuttatni.

- „Kati mondja!”: különböző mozgásos tevékenységeket kell végrehajtaniuk a gyerekeknek, de csak akkor, ha elötte azt hallják: Kati mondja, fogd meg a bal füled és tegyél négy lépést elöre!

Az igazi sport már a nagyobb, iskolás gyerekek számára megfelelő. Az egészségmegőrzés mellett, erkölcsi hatással is bír. Önfegyelemre, kitartásra, bátorságra nevel. A csapatjátékoknál együttmüködésre, összetartásra ösztönöz. Segítheti a beilleszkedést, fejleszti az énképet, feszültségcsökkentő hatása van.

Meg kell találni a gyermek számára legmegfelelőbb sportágat, amit tényleg szívvel-lélekkel csinál, ahova mindig van kedve elmenni, ahol sikereket érhet el. A folyamatos kudarc, a nem megfelelő oktató elveheti a gyermek kedvét a sportolástól. 


\section{Kirándulás}

A kirándulás egy csoport fejlesztésére igencsak alkalmas tevékenység. A szabad levegőn „lenni”, a természetben, fák, növények, állatok között sokkal felszabadultabbak vagyunk, van lehetőségünk a megfigyelésre, tapasztalatok szerzésére, a társakkal való együttlétre, a természetben való helyes viselkedés kialakítására. Lefekhetünk a fübe és nézhetjük az eget, formákat láthatunk a felhőkben, körjátékozhatunk, sportolhatunk, beszélgethetünk, hallgathatjuk a „csendet”. Megfigyelhetjük a színeket, szagokat, érzeteket. Nem csak egy fantasztikus, nyugodt, vidám élményt szerzünk a gyermekek számára, hanem lehetőséget adunk a megnyílásra, az olyan kényes dolgok megbeszélésére, ami foglalkoztatja a gyermekeket, de ennek feldolgozására nincs lehetőség intézményes keretek között (vö.: mezö, 2015). Eközben természetes módon fejlődik erkölcsi érzékük, a természethez való viszonyuk, környezetvédelemmel kapcsolatos tapasztalatuk, tudásuk. A sérült, magatartásproblémákkal küzdő gyermek is jobban elengedi magát, a szorongó, nehezen nyíló gyerekeknek lehetőséget ad akár egyedül is felfedezni a természetet, miközben hallja, látja, hogyan játszanak körülötte társai.

A kirándulásokhoz kapcsolódó fejlesztő játék lehet például:

- Bújjunk a katica bőrébe! Mit érezhetnénk, hogyan élnénk bizonyos állatokként, növényként.

- Menjünk egyre messzebb! Kipróbálhatjuk, ki, milyen messzire merészkedik egyedül, különböző feladatokkal összevonva: Szaladj el a fáig, majd vissza! Érintsd meg a piros virágot, majd tyúklépésben gyere vissza!

\section{Jóga, relaxálás}

Segíti az önbizalom kialakítását, erősíti a test, kitartást ad, egyensúlyba hozza a testet és a lelket, tudatos odafigyelésre tanít. Fejleszti a koncentrációt, kreativitást, beszédértést, kommunikációt, az érzelmi intelligenciát, a testtudatot, a kudarctürést. A gyerekek megtanulják a tudatos légzést, ami az ellazulásban elengedhetetlen, és olyan eszköz kerül a kezükbe, amit bármikor használhatnak, ha pihenni szeretnének, vagy „kikapcsolni”. Az életben fellépő helyzeteket meg tudják majd oldani, a szorongást, félelmeket, bátortalanságot leküzdeni, a stresszt-és kudarcot feldolgozni. A jógát már babakorban el lehet kezdeni, sőt a kismama jóga révén a gyermek már beleszületik ebbe az életmódba.

Az anya-gyermek, illetve egyéb családi kapcsolatok mélyítésére javasolható a családi jóga. Az együttlét eleve jótékony hatással bír, rohanó életünkben, és a szülők megtanulják elfogadni, hogy ne mindig ök irányítsanak, hogy a játék mennyire fontos a gyermek életében!

A jóga alkalmas mozgásproblémák, tanulási nehézségek korrigálására is, mint például a diszlexia, diszgráfia, diszkalkulia, hiperaktivitás.

A relaxáció egy nyugalmi, lazult testi-lélki állapot elérésére irányuló tevékenység. Használható foglalkozások végén, lezárásként, vagy abban az esetben, ha a gyermek már nagyon fáradt, esetleg túl ideges, nyugtalan. Pihenőgyakorlatok lehetnek például:

- Tehénpihenés: háton fekve, felhúzott térdekkel.

- Hullapóz: hanyatt fekve, karuk, lábuk lazán a test mellett.

- Hasalás a füben: hason fekve, áll a két tenyérbe támaszkodik.

- Tigrisfekvés: hason, egyik térd felhúzva a test mellett, ugyanaz a kar behajlítva. Másik láb-kar a test mellett, kinyújtva.

- Légzőgyakorlatok: hasi légzés, tisztítólégzés.

- Fa relaxáció: egy csodálatos erdőben mindenki megkeresi a saját fáját, megnézi minden részét, gyökértől a koronáig, majd a gyermek eggyé válik vele. Így veszi magához ő is energiát.

- Szikla relaxáció: lényege a biztonság, a szabadság érzése.

- Relaxálóhoz ajánlott könyvek: Lite (2014a,b; 2015). 
A foglalkozásokat tarkítják a mondókák, énekek, találós kérdések, nyelvtörők, melyek hozzájárulnak a komplex fejlesztéshez.

\section{Drámajáték}

A drámajáték szintén sokoldalú: a tevékenység mintha jellegü, de a problémák valóságosak, így a szerzett tapasztalatok is. Segítik a gyermeket önmaga és mások megismerésében, elfogadásában, mások tiszteletére nevel. Spontán és irányított játékokkal fejleszti a figyelmet, kommunikációt, empátiát, bátorságot. A játékok során a gyermekek együtt játszanak, aktívan, egymással összedolgozva, így formálja a személyiséget, megkönnyíti a kapcsolatfelvételt és kapcsolattartást. Bizonyos szituációk, helyzetek emlékeztetnek az életben átéltekhez, ezáltal könnyíti az eredeti feladat, probléma megoldását, elfogadását, a helyzet feldolgozását. A drámajáték hatékonyságát illusztráló személyes tapasztalat egy „mesecsoportról”: egy szorongó, visszahúzódó, szüleitől elválni nem tudó gyermek egy-két alkalom után nagyon szeretett oda járni, kezdett feloldódni, olyan szerepeket vállalt magára, amelyben jól érezte magát, és a mások által eljátszott, számára félelemkeltő figurákkal együtt játszva, oldódott feszültsége. Bátrabb, nyitottabb, vidámabb lett, néhány hónap után.

Demonstrációképpen szerepeljen itt néhány példa a drámajátékot alkalmazó foglalkozásokon használható játékokra:

1. Testhelyzet megfigyelés: törökülésben vagy állva, megfigyelik a gyerekek, hogyan helyezkednek el, mit éreznek, mi nyomja őket, mi mivel érintkezik, stb.

2. Koncetrációs légzőgyakorlatok: egy levegővételre kell elmondani: „Nem öt, nem tíz, nem tizenöt, nem húsz..."

3. Üzenetek szavak nélkül: arcjátékok, érzelmek kifejezése és eljátszása, tekintetjátékok (farkasszemezés, „Hová nézett?” járék során a gyermek társa tekintetét követi, „Parancsoló” játék során egy gyermek hátra teszi a kezét és tekintetével parancsokat osztogat), gesztus-játékok (például: „Személyiségtükör” játék során a gyermek elmutogatja egy társát annak gesztusrendszerének felmutatásával, tárgyak jelzése mozdulattal, „Mit mondok én?” játékban a gyermek beáll egy jellemző pozícióba és társainak meg kell mondaniuk az arra jellemző szöveget. Például legyintésnél: „Ah, sebaj!”).

4. Életjátékok: egy családi vasárnap, a felnőttek munkája, közösség-család (lényege az összetartozás kifejezése), őszinteség, titoktartás játkok.

5. Név-tár: a gyerekek jelre elindulnak a teremben. Annyi gyerekkel fognak kezet és mutatkoznak be egymásnak, amennyivel csak tudnak. Minél több nevet kel begyüjteniük.

6. Csomagolás: a csoport fele a padlón fekszik, a másik fele jelre az ellazult, csukott szemü társával ,,azt csinál, amit akar”. Felültetik, asztalra fektetik, hasra fordítják stb.

7. Diszkó: kedvenc slágerre táncolnak a gyerekek, a pedagógus arra vonatkozó instrukcióiram hogy kik és hol vagyunk éppen, ami persze folyamatosan változik.

8. Földrengés: két sorban, szemben ülnek a játékosok egymással. Középen sétál egy gyerek, aki elkiáltja magát: Földrengés! Ekkor a szemben ülöknek helyet kell cserélniük, de a középső játékos is helyet keres, így egynek nem marad szék. Mindig a kimaradó kerül középre.

\section{Zárógondolat}

A felsorolt módszerek mindegyike külön szaktudást igényel, de a szakirodalom szerint is használhatóak bizonyos elemei olyanok számára is, akik nincsenek kellő tudás birtokában. Természetesen a gyermekek személyiségének, érettségének, problémájának megfelelö módszerek megtalálása és alkalmazása körültekintést igénylö feladat. 


\section{Irodalom:}

Balatoni-Huber Vera ésMitró Gabriella (2013): Piros könyv. Letöltés: 2016.12.01. Web: www.nagajoga.hu.

Basford , Johanna (2015): Titkos kert. Budapest: Manó Könyvek Kiadó Kft.

Beck Andrea (2013): A Titoktündér. A titok klub. Veszprém: Beck\&Partners M.Kft.

Beck Andrea (2013): A Titoktündér. Veszprém: Beck\&Partners M.Kft.

Beck Andrea (2014a): A Titoktündér. A titok akadémia. Veszprém: Beck\&Partners M.Kft.

Beck Andrea (2014b): A Titoktündér. A tündérek könyve. Veszprém: Beck\&Partners M.Kft.

Beck Andrea (2015): A Titoktündér. A tündérek kalendáriuma. Veszprém: Beck\&Partners M.Kft.

Beck Andrea (2016): A Titoktündér. Családi könyv. Veszprém: Beck\&Partners M.Kft.

Bernáth László és Révész György (szerk.)(2002): A behaviorizmus. In: A pszichológia alapjai. Budapest: Tertia Kiadó, 33-46.

Boldizsár Ildikó (2014): Boszorkányos mesék. Budapest: Móra Könyvkiadó.

Deákné B. Katalin (2013): Befejezetlen történetek. Budapest: Tudatos Lépés Kft.

Domány Mária (2001): A bábjáték varázsa. Zenta: Thurzó Lajos Közmüvelödési Központ.

Ende, Michael (2003): Álomfaló csodamanó. Szeged: Minerva Kiadó.

Gabnai Katalin (2015): Drámajátékok. Budapest: Helikon Kiadó.

Gál Éva, Karádi Róbert, Szentesi Csaba és Varró Dániel (2007): Verses-képes gyerekjóga. Budapest: Jaffa Kiadó.

Hudra Nikoletta (2008): A viselkedészavarok iskolai korrekciója. Új Pedagógiai Szemle 03. Letöltés: 2016.12.01. Web: https://www.ofi.hu/tudastar/hudra-nikoletta 2016. 10. 12.

Kádár Annamária (2014): A félelmek, szorongások kezelése gyermekkorban. In: Mesepszichológia 2. Budapest: Kulcslyuk Kiadó.160-193.

Kaposi László (szerk.)(2013): Játékkönyv. Budapest: II. Kerületi Közhasznú Nonprofit Kft.

Kertész Erzsi (2016).: Nem mese. Budapest: Pozsonyi Pagony Kft.

Kertész Erzsi (2016): Nem mese. Budapest: Pozsonyi Pagony Kft.

Kormos István (2016a): Mese Vackorról, egy piszén pisze kölyökmackóról. Budapest: Móra Könyvkiadó.

Kormos István (2016b): Vackor az első bében. Budapest: Móra Könyvkiadó.

Lengyel Boglárka és Rónai Róbert (2012): Mesetandem - Bátorító mesék. Danas Kiadó, Budapest.

Lori Lite (2014): A dühös polip. Budapest: Kulcslyuk Kiadó.

Lori Lite (2014): A vidra öböl. Budapest: Kulcslyuk Kiadó.

Lori Lite (2015): Buborékkeringés. Budapest: Kulcslyuk Kiadó.

Marék Veronika (2013): Laci és az oroszlán. Budapest: Móra Könyvkiadó.

Mehler, Jacques, Dupoux, Emmanuel és Gevanin Judit (2008): Az emberi gépezet. In: Ember születik. Budapest: Gondolat Kiadó 28-43.

Mező Katalin (2015): Kreativitás és élménypedagógia. Debrecen: Kocka Kör.

Mészáros Bori (2015): Az álomtündér. Budapest: Látóhatár Kiadó.

Ranschburg Jenő (1995): A szorongó gyermek. In: Félelem, harag, agresszió. Budapest: Nemzeti Tankönyvkiadó. 80-90.

Smith, Keri (2016): Nyírd ki ezt a naplót. Szeged: Maxim Könyvkiadó Kft. 